\title{
SIFAT ANTIBAKTERI DARI DAUN Tephrosia vogelii TERHADAP VIBRIOSIS
}

\author{
ERI BACHTIAR ${ }^{1}$, YANA MAOLANA SYAH ${ }^{2}$, DAN LIA DEWI JULIAWATY ${ }^{2}$
}

${ }^{1}$ Program Studi Ilmu Kelautan, Fakultas Perikanan dan Ilmu Kelautan, Universitas Padjadjaran,

Jl. Raya Bandung-Sumedang KM 21, Jatinangor, Sumedang

${ }^{2}$ Program Studi Kimia, Fakultas Matematika dan Ilmu Pengetahuan Alam, Institut Teknologi Bandung,

Jl. Ganesha No. 10, Lb. Siliwangi, Coblong, Kota Bandung

*alamat email korespondensi: e.bachtiar@unpad.ac.id

\begin{abstract}
Informasi Artikel
\section{Abstrak/Abstract}

Riwayat Naskah :

Diterima pada 12

April 2019

Diterima setelah

direvisi pada 4 Juli

2019

Diterbitkan pada 5

Juli 2019

Sektor kelautan dan perikanan merupakan salah satu sumber andalan dalam produksi pembangunan perikanan di Indonesia. Udang merupakan salah satu komoditas unggulan utama dalam menunjang produksi pendapatan devisa non migas. Untuk mencapai target produksi sesuai dengan yang diharapkan, berbagai permasalahan menghambat upaya peningkatan produksi tersebut, antara lain kegagalan produksi akibat penyakit oleh bakteri Vibrio, sehingga penyakit ini dikenal sebagai 'vibriosis'. Salah satu pencarian senyawa yang bersifat antibakteri adalah dengan cara melakukan penapisan terhadap senyawa-senyawa alam. Salah satu sumber senyawa alam adalah dari tumbuhan Tephrosia vogelii. Penelitian ini bertujuan untuk mengidentifikasi dan mengisolasi senyawa dari tumbuhan $T$. vogelii sebagai sumber senyawa antibakteri terhadap dua bakteri Vibrio yaitu Vibrio alginolitycus dan Vibrio harveyi. Bahan ekstrak dibuat dengan metode maserasi menggunakan pelarut aseton, sementara uji antibakteri dilakukan dengan metode difusi agar secara in vitro. Deguelin dan

Kata Kunci: Udang windu; Vibriosis; Vibrio alginolitycus; Vibrio harveyi; Tephrosia vogelii. tefrosin kemudian diisolasi dari ekstrak aseton daun $T$. vogelii. dengan metode difusi agar senyawa deguelin memberikan nilai inhibisi 6,3 $\mathrm{mm}$ terhadap $V$. harveyi dan 6,2 $\mathrm{mm}$ terhadap $V$ alginolitycus. Sedangkan tefrosin memberikan nilai inhibisi $6,3 \mathrm{~mm}$ terhadap $V$. harveyi dan 6,6 mm terhadap $V$ alginolitycus. Ini adalah evaluasi antibakteri pertama dari deguelin dan tefrosin terhadap dua bakteri yang diuji.
\end{abstract}

Keywords: Tiger shrimp; Vibriosis; Vibrio alginolitycus; Vibrio harveyi; Tephrosia vogelii.
The marine and fisheries sector is one of the mainstay sources in fisheries development production in Indonesia. Shrimp is one of the main leading commodities in supporting the production of non-oil foreign exchange income. To achieve the production target as expected, various problems hinder efforts to increase production, including production failure due to disease by Vibrio bacteria, so this disease is known as 'vibriosis'. One of the searches for compounds that are antibacterial is by screening natural compounds. One source of natural compounds is from the plant Tephrosia vogelii. This study aims to identify and isolate compounds from plant $T$. vogelii as a source of antibacterial compounds against two Vibrio bacteria namely Vibrio alginolitycus and Vibrio harveyi. The extract material was made by maceration method using acetone solvents, while the antibacterial test was carried out by agar diffusion method in vitro. Deguelin and tefrosin were then isolated from the acetone extract of $T$. vogelii leaves. with the diffusion method so that deguelin compounds provide an inhibitory value of $6.3 \mathrm{~mm}$ against $V$. harveyi and $6.2 \mathrm{~mm}$ against $V$ alginolitycus. Whereas tephrosine gave an inhibition value of $6.3 \mathrm{~mm}$ against $V$. harveyi and $6.6 \mathrm{~mm}$ against $V$ alginolitycus. This is the first antibacterial evaluation of deguelin and tefrosin against the two bacteria tested.

\section{PENDAHULUAN}

Penyakit pada udang windu umumnya dapat disebabkan oleh salah satu atau kombinasi dari infeksi virus, bakteri, jamur, dan parasit. Pada infeksi karena bakteri, vibriosis merupakan salah satu penyakit yang penting, yang disebabkan oleh bakteri Vibrio dengan agen penginfeksi meliputi Vibrio alginolitycus, $V$. harveyi, dan $V$. parahaemolitycus. Penyakit ini seringkali dikaitkan dengan kerugian yang cukup besar pada pertambakan udang, dan penyebarannya terjadi hampir di seluruh dunia. Tingkat infeksi pada vibriosis sangat tinggi dan bersifat akut, sehingga dapat menyebabkan kematian larva udang sampai $100 \%$ dalam waktu 1-2 hari. Bakteri ini juga cukup sulit diberantas atau udang yang terserang tidak dapat disembuhkan [1].

Di Indonesia, penyakit vibriosis pada udang windu telah dilaporkan terjadi hampir di seluruh wilayah, meliputi Sumatera Utara, Lampung, Jawa Barat, Jawa Tengah dan Sulawesi Tenggara. 
Akibat infeksi ini, produksi udang windu akhirakhir ini mengalami penurunan, dan menjadi gejala global pada peternakan udang [2].

Penanggulangan penyakit vibriosis adalah melalui pencegahan, sehingga mampu mengurangi kemungkinan udang terpapar oleh bakteri Vibrio. Pemberian antibiotik merupakan cara yang sering dilakukan untuk mengatasi vibriosis. Antibiotik yang lazim digunakan oleh peternak udang, di antaranya adalah amoksisilin, gentamisin, kloramfenikol, dan tetrasiklin [3]. Sama halnya dengan infeksi penyakit bakteri yang menyerang pada manusia maka bakteri Vibrio juga dapat mengembangkan resistensi terhadap obat-obat antibiotik tersebut. Selain itu, penggunaan antibiotik pada peternakan udang juga dapat menimbulkan permasalahan lain, yaitu menyebabkan adanya residu (akumulasi) antibiotik pada tubuh udang. Adanya residu tersebut tentu saja tidak disukai oleh para konsumen karena sifat toksik yang melekat dari obat-obat tersebut dapat terakumulasi di dalam tubuh manusia [3]. Dengan demikian, pencarian obat-obat antibiotik baru yang lebih aman menjadi sangat penting untuk dilakukan.

Salah satu pencarian senyawa yang bersifat antibakteri adalah dengan cara melakukan penapisan terhadap senyawa-senyawa alam. Salah satu sumber senyawa alam adalah dari tumbuhan obat. Pendekatan ini akan menghasilkan senyawa antibakteri dengan target kepada sistem metabolisme bakteri, sehingga menyebabkan penghambatan pertumbuhan bakteri, bahkan kematian bakteri itu sendiri [4]. Pemanfaatan tumbuhan obat oleh masyarakat luas sebagai antibakteri telah sejak lama dilakukan dan hal ini menunjukkan bahwa sifat toksik senyawa aktif dalam tumbuhan tersebut relatif sangat rendah dan aman untuk dikonsumsi. Sebagai contoh, sejumlah ekstrak dari tumbuhan obat India baik bagian akar, biji dan daun memiliki aktivitas antibakteri terhadap $V$. harveyi dan dapat meningkatkan kelangsungan hidup udang windu (Penaeus monodon) [5].

Tumbuhan genus Tephrosia yang sebagian besar tumbuhan ini lebih bermanfaat di bidang pertanian dan perikanan. Penelitian yang telah dilakukan oleh Karidan, 1997 [6], yang melaporkan bahwa daun $T$. vogelii dikenal sebagai tanaman kacang babi mempunyai kemampuan membunuh keong mas (Pomace canaliculata) atau dapat juga disebut bersifat moluskasida alami. Selain itu, tumbuhan Tephrosia (Tephrosia vogelii, $T$. candida, $T$. virginiana) mempunyai kemampuan sebagai insektisida alami dan racun ikan seperti yang telah dilaporkan oleh MoralloRijesuss (1986) dalam Sastrosiswojo, 2002 [7].
Sementara itu, di Telangana (India) tumbuhan Vempali ( $T$. purpurea L) daunnya sering dimanfaatkan untuk penawar racun sengatan kalajengking, sedangkan akarnya biasa digunakan oleh masyarakat di India untuk obat sakit perut [8]. Selain itu, ditemukan juga beberapa hasil penelitian mengenai aktivitas farmakologi tumbuhan $T$. clophylla dan $T$. candida yaitu bersifat sitotoksik serta $T$. pumila yang bersifat antiprotozoa [9].

Selain itu, menurut Citarasu, 2000 [5], melaporkan bahwa ekstrak dari tumbuhan obat di India (Myristica fragrans, Ocium sanctum dan Withania somnifera) aktif terhadap $V$. harveyi. Pada tahun 2013, dilaporkan pula dua senyawa yang bersifat antibakteri terhadap $V$. harveyi yaitu 4-aminofenol dan 4-hidroksibenzaldehid dari tumbuhan obat India yaitu Dilobela thouarsii [10]. Selanjutnya, senyawa alkaloid yaitu sanguinarin yang memiliki aktivitas antibakteri terhadap $V$. harveyi telah diisolasi pula dari tumbuhan Macleya microcarpa [11]. Berdasarkan uraian tersebut, maka kajian tumbuhan obat Indonesia dalam rangka pencarian senyawa aktif antibakteri pada vibriosis udang windu khususnya $V$. harveyi sangat penting dilakukan untuk mengembangkan penggunaan tumbuhan obat Indonesia dalam peningkatan produksi budidaya udang windu di Indonesia.

\section{EKSPERIMEN}

Penelitian ini dilakukan isolasi senyawasenyawa fenolik dari tumbuhan famili Leguminosea (Fabaceae) yaitu daun Tephrosia vogelii. Metode yang digunakan meliputi ekstraksi pada suhu kamar (maserasi) menggunakan pelarut aseton, dilanjutkan dengan fraksinasi fasa cair-cair terhadap ekstrak aseton menggunakan pelarut yang berbeda kepolarannya, kemudian diikuti oleh pemisahan dan pemurnian menggunakan beberapa teknik kromatografi, di antaranya kromatografi cair vakum (KCV), kromatografi gravitasi $(\mathrm{KG})$, kromatografi radial (KR), dan rekristalisasi. Kemurnian senyawa hasil isolasi ditetapkan berdasarkan analisis kromatografi lapis tipis (KLT) dengan tiga sistem eluen.

\section{Material}

Bahan tumbuhan yang digunakan yaitu daun Tephrosia vogelii yang dikumpulkan pada bulan Februari 2018 dari daerah di Cisarua, Cimahi. Pelarut yang digunakan untuk isolasi merupakan pelarut teknis yang telah didestilasi dan pelarut pro analisis (p.a) antara lain metanol teknis, aseton teknis etil asetat teknis, $n$-heksan 
teknis, dan kloroform pro analisis. Jenis-jenis silika gel yang digunakan dalam penelitian ini antara lain (Si-gel) $60 \mathrm{GF}_{254}$ (Merck) untuk KCV, (Si-gel) $60 \mathrm{PF}_{254}$ (Merck) untuk KR, (Si-gel) (Merck) ukuran 200 mesh untuk KG, (Si-gel) (Merck) 35-70 mesh untuk impregnasi dan plat alumunium berlapis silika gel (Merck) Kiesgel 60 $\mathrm{GF}_{254}$ dengan ketebalan $0,25 \mathrm{~mm}$ untuk analisis KLT. Pereaksi untuk uji kualitatif yaitu serium sulfat $1,5 \%$ dalam asam sulfat.

\section{Instrumentasi}

Struktur molekul senyawa hasil isolasi ditetapkan berdasarkan hasil analisis spektroskopi resonansi magnet inti $1 \mathrm{D}\left({ }^{1} \mathrm{H}\right.$ NMR, ${ }^{13} \mathrm{C}$ NMR) dan 2D (COSY, HSQC, HMBC dan NOESY). Spektrum ${ }^{1} \mathrm{H}$ NMR dan ${ }^{13} \mathrm{C}$ NMR diukur dengan spektrometer Agilent DD2 $500\left({ }^{1} \mathrm{H} 500 \mathrm{MHz},{ }^{13} \mathrm{C}\right.$ $125 \mathrm{MHz}$ ) serta digunakan pelarut DMSO dan $\mathrm{CDCl}_{3}$. Penentuan bioaktivitas antibakteri senyawa hasil isolasi terhadap bakteri patogen, yaitu Vibrio alginolitycus dan Vibrio harveyi menggunakan metode difusi yang mengacu kepada standar M7-A9 Clinic and Laboratory Standards Institute [12].

\section{Prosedur}

\section{Isolasi Senyawa-senyawa dari Daun T. vogelii}

Serbuk halus daun $T$. vogelii sebanyak 1,0 $\mathrm{kg}$ dimaserasi dengan aseton (3 x @ 24 jam), kemudian ekstrak aseton dikeringkan pada tekanan rendah dan diperoleh ekstrak pekat aseton sebanyak $82 \mathrm{~g}$ berupa padatan berwarna hijau. Tahap selanjutnya terhadap ekstrak yang dihasilkan dilakukan fraksinasi lebih lanjut dengan teknik KCV menggunakan silika gel sebagai fasa diam dengan pelarut $n$-heksan:etil asetat dengan kepolarannya, yaitu 9:1, 8:2, 6:4, 5:5, 3:7 menghasilkan enam belas fraksi (1 - 16) kemudian dimurnikan secara berulang menggunakan KR (silika gel, eluen bervariasi) sehingga diperoleh senyawa-senyawa yaitu deguelin (1), dan tefrosin (2). Senyawa $1(13,6 \mathrm{mg})$ berupa padatan bewarna putih, diperoleh dari hasil pemurnian fraksi 9 (1 g) dengan KCV menggunakan silika gel sebagai fasa diam dengan pelarut $n$-heksan:diisopropil eter menghasilkan delapan belas fraksi $(1-18)$ kemudian subfraksi DKB-9-1718 (103 mg) dimurnikan dengan KR (silika gel, $n$ heksan:diisopropil eter). Senyawa 2 (37,5 mg) berupa padatan putih, diperoleh dari hasil pemurnian subfraksi DKB-9-1213 (114 mg) dengan KR (silika gel, $n$-heksan:diisopropil eter).

\section{Uji Antibakteri}

Penapisan ekstrak dan senyawa murni tumbuhan obat Indonesia terhadap antibakteri menggunakan metode difusi secara in vitro. Hal ini dilakukan untuk mengetahui kemampuan masing-masing ekstrak tumbuhan obat Indonesia sebagai sumber senyawa antibakteri dalam menghambat pertumbuhan bakteri patogen yang menyerang pada udang yaitu Vibrio alginolitycus, dan Vibrio harveyi. Uji zona hambat dilakukan dengan menggunakan kertas cakram diameter 6 $\mathrm{mm}$ dibuat dari kertas saring whatman no.42 dan diteteskan dengan masing-masing ekstrak tumbuhan obat Indonesia menggunakan mikropipet pada konsentrasi 1000 ppm.

Peralatan dan bahan yang digunakan untuk uji zona hambat disterilisasi terlebih dahulu dengan autoclave. Metode pengerjaan dilakukan secara steril di ruang laminar flow untuk mencegah kontaminasi. Kertas saring Whatman dengan diameter $6 \mathrm{~mm}$ yang telah diberi masingmasing ekstrak tumbuhan obat Indonesia dipersiapkan lalu dipetakkan di atas media Cawan Petri agar MHA yang telah diinokulasi dengan masing-masing bakteri Vibrio alginolitycus, dan Vibrio harveyi sebanyak $0,5 \mathrm{~mL}$ dengan kepadatan $10^{8} \mathrm{CFU} / \mathrm{mL}$. Masing-masing perlakuan konsentrasi diulang tiga kali. Cawan Petri kemudian diinkubasikan selama 24 jam pada suhu $35^{\circ} \mathrm{C}$ dalam inkubator. Diameter zona hambat yang dihasilkan pada uji ini kemudian diukur dengan menggunakan jangka sorong.

\section{HASIL DAN PEMBAHASAN}

Senyawa 1 (Gambar 1) diperoleh dalam bentuk padatan berwarna coklat tua. Spektrum ${ }^{13} \mathrm{C}$ NMR (Tabel 1) senyawa ini memperlihatkan adanya 23 sinyal karbon, yang meliputi sinyalsinyal untuk satu gugus $\mathrm{C}=\mathrm{O}\left(\delta_{\mathrm{C}} 189,2\right) \mathrm{ppm}$, lima C-oksiaril $\left(\delta_{\mathrm{C}} 160,1 ; 156,9 ; 149,5 ; 147,4\right.$ dan $143,8) \mathrm{ppm}$, enam $\mathrm{CH}$-aromatik $\left(\delta_{\mathrm{C}} 128,7 ; 128,5\right.$; $115,7 ; 111,5 ; 110,4$ dan 100,9$)$ ppm, empat Ckwarterner aromatik $\left(\delta_{\mathrm{C}} 112,7 ; 109,1 ; 104,8\right.$ dan 77,7) ppm, dua C-metin $\left(\delta_{\mathrm{C}} 72,4\right.$ dan 44,4$) \mathrm{ppm}$, satu $\mathrm{CH}_{2}\left(\delta_{\mathrm{C}} 66,3\right) \mathrm{ppm}$, dua gugus $-\mathrm{OCH}_{3}\left(\delta_{\mathrm{C}}\right.$ $56,3$ dan 55,8$) \mathrm{ppm}$, dan dua gugus metil $\left(\delta_{\mathrm{C}} 28,5\right.$ dan 28,1) ppm. Parameter sinyal-sinyal karbon tersebut sangat mirip dengan degeulin yang diperoleh pada tumbuhan yang sama oleh Vasconcelos dkk., 2012 [13]. Sesuai dengan struktur degeulin, pada spektrum ${ }^{1} \mathrm{H}$ NMR menunjukkan adanya satu cincin 2,2-dimetil piran $\left(\mathrm{C}_{5}\right)\left(\delta_{\mathrm{H}} 6,63,5,56,1,45\right.$ dan $1,38, \delta_{\mathrm{C}} 128,7,115,7$, $77,7,28,5$ dan 28,1$)$ ppm. Selain itu juga teramati sinyal-sinyal untuk dua gugus $-\mathrm{OCH}_{3}\left(\delta_{\mathrm{H}} 3,80\right.$ 
dan 3,77) ppm, sehingga senyawa ini mengandung kerangka dasar- $\mathrm{C}_{16}$. Pada spektrum ${ }^{1} \mathrm{H}$ NMR di daerah alifatik ditemukan empat sinyal $\left(\delta_{\mathrm{H}} 4,90\right.$, 4,64, 4,62 dan 4,19) ppm yang sesuai untuk unit struktur $-\mathrm{O}-\mathrm{CH}_{2}-\mathrm{CH}(\mathrm{O})-\mathrm{CH}(\mathrm{C}=\mathrm{O})(\mathrm{Ar})-$, Keberadaan unit struktur tersebut adalah khas untuk kelompok rotenoid pada turunan isoflavon. Adanya dua sinyal aromatik terkopling-orto $\left(\delta_{\mathrm{H}}\right.$ 7,75 dan 6,65) ppm dan dua sinyal aromatik lainnya yang terkopling-para $\left(\delta_{\mathrm{H}} 6,79\right.$ dan 6,45$)$ ppm, maka dapat disarankan senyawa 1 adalah deguelin. Bukti lebih lanjut struktur 1 sebagai deguelin diperoleh dari adanya kesesuaian yang tinggi pada parameter NMR senyawa ini dengan yang dilaporkan untuk deguelin Vasconcelos dkk., 2012 [13]. Karena kesamaan tersebut, terutama sinyal-sinyal yang melibatkan C-6, C-6a dan C- 12a, maka stereokimia di C-6a dan C-12a ditetapkan sebagai cis [13].<smiles>COc1cc2c(cc1OC)[C@@H]1C(=O)c3ccc4c(c3O[C@H]1CO2)C=CC(C)(C)O4</smiles>

Gambar 1. Senyawa 1 dalam $\mathrm{CDCl}_{3}$

Tabel 1. Data NMR senyawa 1 dalam $\mathrm{CDCl}_{3}$

\begin{tabular}{|c|c|c|c|c|}
\hline \multirow{2}{*}{ No. $\mathrm{C}$} & \multicolumn{2}{|c|}{$\delta_{\mathrm{H}}($ mult.,$J$ dalam Hz) } & \multicolumn{2}{|c|}{$\delta_{\mathrm{C}}$} \\
\hline & 3 & 3* & 3 & $3^{*}$ \\
\hline 1 & $6,79(s)$ & $6,79(s)$ & 110,4 & 110,0 \\
\hline $1 \mathrm{a}$ & - & - & 104,4 & 104,4 \\
\hline 2 & - & - & 143,8 & 143,4 \\
\hline 3 & - & - & 149,5 & 149,0 \\
\hline 4 & $6,45(s, 8,7)$ & $6,45(s, 8,6)$ & 100,9 & 100,5 \\
\hline $4 a$ & - & - & 147,4 & 147,0 \\
\hline \multirow[t]{2}{*}{6} & $4,64(d d, 12,3 ; 5,9)$ & $4,82(d d, 12)$ & 66,3 & 65,9 \\
\hline & $4,62(d d, 12,4 ; 4,0)$ & $4,17(d d, 12)$ & & \\
\hline $6 a$ & $4,90(s)$ & $4,90(s)$ & 72,4 & 72,0 \\
\hline $7 \mathrm{a}$ & - & - & 156,9 & 156,5 \\
\hline 8 & - & - & 109,1 & 108,7 \\
\hline 9 & - & - & 160,1 & 159,7 \\
\hline 10 & $6,65(d, 8,9)$ & $6,45(d, 8,6)$ & 111,5 & 111,1 \\
\hline 11 & $7,75(d, 8,9)$ & $7,51(d, 8,6)$ & 128,5 & 128,3 \\
\hline $11 \mathrm{a}$ & - & - & 112,7 & 112,4 \\
\hline 12 & - & - & 189,2 & 188,9 \\
\hline $12 \mathrm{a}$ & $4,19(d, 4,0)$ & $3,83(d, 4)$ & 44,4 & 43,9 \\
\hline $2^{\prime}$ & - & - & 77,7 & 77,3 \\
\hline 3 & $5,56(d, 10,1)$ & $5,55(d, 9,8)$ & 128,7 & 128,1 \\
\hline 4 & $6,63(d, 10,1)$ & $6,64(d, 9,8)$ & 115,7 & 115,3 \\
\hline 5 , & $1,38(s)$ & $1,36(s)$ & 28,5 & 28,1 \\
\hline 6 ' & $1,45(s)$ & $1,45(s)$ & 28,1 & 27,7 \\
\hline $3-\mathrm{OCH}_{3}$ & $3,80(s)$ & $3,74(s)$ & 56,3 & 55,9 \\
\hline $2-\mathrm{OCH}_{3}$ & $3,77(s)$ & $3,77(s)$ & 55,8 & 55,4 \\
\hline
\end{tabular}

$* 13 \mathrm{C}$ NMR diukur pada $125 \mathrm{MHz}$ dalam $\mathrm{CDCl}_{3}$ [13]

Senyawa 2 (Gambar 2) juga diperoleh sebagai padatan berwarna coklat. Spektrum ${ }^{13} \mathrm{C}$ NMR (Tabel 2), senyawa ini mirip dengan spektrum dari senyawa 1, kecuali sinyal karbon $\mathrm{CH}\left(\delta_{\mathrm{C}} 44,4\right) \mathrm{ppm}$ pada senyawa 1 hilang diganti dengan sinyal karbon $\mathrm{C}-\mathrm{O}$ tersier $\left(\delta_{\mathrm{C}} 67,5\right) \mathrm{ppm}$ pada senyawa 2 . Sementara itu, pada spektrum ${ }^{1} \mathrm{H}$ NMR teridentifikasi adanya cincin 2,2dimetilpiran $\left(\delta_{\mathrm{H}} 6,62,5,57,1,46\right.$ dan 1,39$) \mathrm{ppm}$, dua sinyal $-\mathrm{OCH}_{3}\left(\delta_{\mathrm{H}} 3,82\right.$ dan 3,74$) \mathrm{ppm}$, dua sinyal aromatik terkopling-orto $\left(\delta_{\mathrm{H}} 7,74\right.$ dan 6,47$)$ ppm dan sepasang sinyal aromatik dengan orentasi-para $\left(\delta_{\mathrm{H}} \quad 6,57\right.$ dan 6,49$) \quad \mathrm{ppm}$. Berdasarkan ciri-ciri tersebut maka dapat disarankan senyawa 2 adalah turunan 12a-hidroksi dari deguelin (3) yaitu senyawa yang dikenal sebagai tefrosin (2). Perbandingan data NMR senyawa 2 dengan data NMR tefrosin Vasconcelos dkk., 2012 [13] menghasilkan kesamaan yang tinggi pada parameter NMR-nya. 
al-Kimiya, Vol. 6, No. 1 (9-14) Juni 2019/Syawwal 1440 H

Tabel 2. Data spektrum ${ }^{1} \mathrm{H},{ }^{13} \mathrm{C}-\mathrm{NMR}$ dan $\mathrm{HMBC}$ senyawa 2 dalam $\mathrm{CDCl}_{3}$

\begin{tabular}{|c|c|c|c|c|}
\hline \multirow{2}{*}{ No. C } & \multicolumn{2}{|l|}{$\delta_{\mathrm{H}}($ mult..$J \mathrm{~Hz})$} & & \multirow{2}{*}{$\mathrm{HMBC}\left({ }^{1} \mathrm{H} \leftrightarrow{ }^{13} \mathrm{C}\right)$} \\
\hline & 4 & 4 & 4* & \\
\hline 1 & $6,57(s)$ & 109,4 & 109,8 & $\mathrm{C}-1, \mathrm{C}-2, \mathrm{C}-3, \mathrm{C}-1 \mathrm{a}, \mathrm{C}-4 \mathrm{a}, \mathrm{C}-12 \mathrm{a}$ \\
\hline $1 \mathrm{a}$ & - & 108,6 & 108,8 & - \\
\hline 2 & - & 144,0 & 144,2 & - \\
\hline 3 & - & 151,1 & 151,4 & - \\
\hline 4 & $6,49(s)$ & 101,1 & 101,3 & $\mathrm{C}-2, \mathrm{C}-3, \mathrm{C}-4$ \\
\hline $4 a$ & - & 148,4 & 148,6 & \\
\hline \multirow[t]{2}{*}{6} & $4,65(d d, 12,1 ; 2,5)$ & 63,9 & 64,0 & C-6a, C-12a \\
\hline & $4,49(d d, 12,1 ; 2,5)$ & & & \\
\hline $6 a$ & $4,62(d d, 2,4 ; 1,2)$ & 76,3 & 76,5 & $\mathrm{C}-6, \mathrm{C}-1 \mathrm{a}, \mathrm{C}-12, \mathrm{C}-12 \mathrm{a}$ \\
\hline $7 \mathrm{a}$ & - & 156,7 & 156,8 & - \\
\hline 8 & - & 109,1 & 109,3 & - \\
\hline 9 & - & 160,8 & 160,9 & - \\
\hline 10 & $6,47(d, 8,9)$ & 111,9 & 112,0 & C-8, C-9, C-10, C-11 \\
\hline 11 & $7,74(d, 8,9)$ & 128,5 & 128,7 & C-10, C-7a \\
\hline $11 \mathrm{a}$ & - & 111,1 & 111,2 & - \\
\hline 12 & - & 191,4 & 191,5 & - \\
\hline $4^{\prime}$ & $6,62(d, 10,1)$ & 115,4 & 115,5 & C-7a, C-9, C-4' \\
\hline $3^{\prime}$ & $5,57(d, 10,1)$ & 128,8 & 128,9 & C-4', C-5', C-8 \\
\hline $2^{\prime}$ & - & 78,0 & 78,1 & - \\
\hline $6^{\prime}$ & $1,46(s)$ & 28,3 & 28,4 & C-5', C-6', C-3' \\
\hline $5^{\prime}$ & $1,39(s)$ & 28,5 & 28,7 & $\mathrm{C}-5^{\prime}, \mathrm{C}-6^{\prime}, \mathrm{C}-2^{\prime}$ \\
\hline $2-\mathrm{OCH}_{3}$ & $3,74(s)$ & 55,9 & 56,0 & $\mathrm{C}-2$ \\
\hline $3-\mathrm{OCH}_{3}$ & $3,82(s)$ & 56,4 & 56,5 & $\mathrm{C}-3$ \\
\hline $12 \mathrm{a}-\mathrm{OH}$ & $4,52(s)$ & 67,5 & 67,6 & C-12a, C-6a \\
\hline
\end{tabular}

*13 C NMR diukur pada $125 \mathrm{MHz}$ dalam $\mathrm{CDCl}_{3}$ [13]

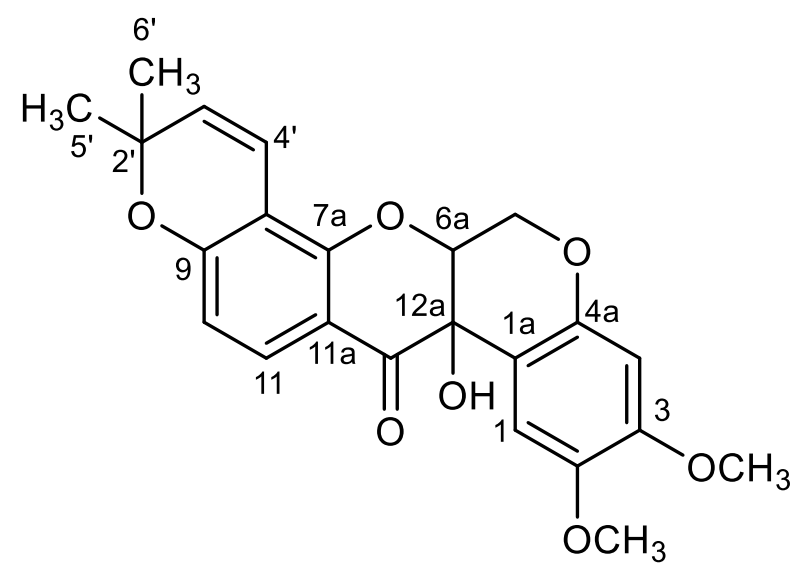

Gambar 2. Senyawa 2 dalam $\mathrm{CDCl}_{3}$

Hasil uji aktivitas antibakteri secara in vitro dengan metode difusi terhadap senyawa murni hasil isolasi dari daun Tephrosia vogelli yang menghasilkan dua senyawa murni memperlihatkan bahwa senyawa hasil isolasi pada umumnya tidak dapat menghambat pertumbuhan beberapa bakteri uji dengan tingkat aktivitas zona hambat yang rendah yaitu mulai dari 6,0-6,6 $\mathrm{mm}$. Menurut Green wood, 1995 [14] respon hambatan pertumbuhan bakteri dapat diklasifikasi seperti yang terlihat pada Tabel 3 .
Tabel 3. Klasifikasi respon hambatan pertumbuhan bakteri

\begin{tabular}{cc}
\hline $\begin{array}{c}\text { Diameter zona } \\
\text { hambat }\end{array}$ & $\begin{array}{c}\text { Respon hambatan } \\
\text { pertumbuhan }\end{array}$ \\
\hline$>20 \mathrm{~mm}$ & Kuat \\
$16-19 \mathrm{~mm}$ & Sedang \\
$10-15 \mathrm{~mm}$ & Lemah \\
$<10 \mathrm{~mm}$ & Tidak ada \\
\hline
\end{tabular}

Berdasarkan nilai zona hambat, senyawa deguelin memberikan nilai inhibisi $6,3 \mathrm{~mm}$ terhadap $V$. harveyi dan $6,2 \mathrm{~mm}$ terhadap $V$ alginolitycus. Sedangkan tefrosin memberikan nilai inhibisi $6,3 \mathrm{~mm}$ terhadap $V$. harveyi dan 6,6 $\mathrm{mm}$ terhadap $V$ alginolitycus. Ini adalah evaluasi antibakteri pertama dari deguelin dan tefrosin terhadap dua bakteri yang diuji [14].

\section{SIMPULAN}

Penelitian ini telah dilakukan kajian fitokimia terhadap tumbuhan Tephrosia vogelii, yang berhasil memisahkan dua senyawa murni, yaitu deguelin (1), dan tefrosin (2). Senyawa 1 merupakan senyawa turunan isoflavanon, sedangkan senyawa $\mathbf{2}$ merupakan senyawa turunan rotenoid yang khas dari tumbuhan Tephrosia vogelii. Evaluasi lebih lanjut sifat antibakteri kedua senyawa tersebut memperlihatkan bahwa 
senyawa hasil isolasi pada umumnya tidak dapat menghambat pertumbuhan beberapa bakteri uji dengan tingkat aktivitas zona hambat atau nilai inhibisi yang rendah yaitu mulai dari 6,0 - 6,6 $\mathrm{mm}$. Berdasarkan nilai inhibisi, senyawa deguelin memberikan nilai inhibisi $6,3 \mathrm{~mm}$ terhadap $V$. harveyi dan $6,2 \mathrm{~mm}$ terhadap $V$ alginolitycus. Sedangkan tefrosin memberikan nilai inhibisi 6,3 mm terhadap $V$. harveyi dan $6,6 \mathrm{~mm}$ terhadap $V$ alginolitycus.

\section{UCAPAN TERIMA KASIH}

Pada kesempatan ini penulis menyampaikan ucapan terima kasih kepada Kementrian Riset, Teknologi, dan Pendidikan Tinggi, Direktorat Jenderal Sumberdaya Iptek dan Dikti yang telah memberikan Beasiswa Pendidikan Pascasarjana Dalam Negeri (BPP-DN).

\section{REFERENSI}

[1] A. Taslihan, S. Bambang, dan J. Suantika, Pengendalian Penyakit pada Pembenihan Udang Windu. Jepara: Balai Budidaya Air Payau, 1991.

[2] D. Lightner, "Indonesian marine shrimp culture industry : Observation, constraints and recomendation resulting from a survey of culture areas.," 1990.

[3] A. Rukyani, P. Taufik, dan Taukhid, "Penyakit Kunang-kunang (luminescent vibriosis) dan Cara Penanggulangan Benur di Hatchery Udang Windu," Jurnal Litbang Pertanian, 2., pp. 1-17., 1992.

[4] M. Saleem, M. Nazir, M.S. Ali, H. Hussain, Y.S.Lee, N. Riaz, dan A. J. Jabbar "Antimicrobial natural products: An update on future antibiotic drug candidates," Natural Product Reports, 27, , pp. 238-254., 2010.

[5] T. Citarasu, "Developing artemia enrichment ayurvedic diet for promoting growth and reducing stress induced diseases in Penaeus sp. Thesis, ," India., 2000.

[6] A. Kardinan dan M. Iskandar, "Pengaruh beberapa jenis ekstrak tanaman sebagai moluskasida nabati terhadap keong mas (Pomacea canaliculata)", Jurnal Perlindungan Tanaman Indonesia, vol. 3, no. 2, pp. 86-92., 1997.
[7] S. Sastrosiswojo, "Kajian Sosial Ekonomi dan Budaya Penggunaan Biopestisida di Indonesia.," Yogyakarta, Tanggal 7 Agustus 2002., 2002.

[8] N. Ramakrishna, E.M. Sunitha, Ch. Saidulu, dan A. Rajani, "Studies on some medicinal plants of Leguminoseae family in Adilabad district, Telangana State, India" International Journal of Pharmaceutical Sciences Review and Research, vol. 30, no. 1, pp. 111-112., 2015.

[9] S. Touqeer, M.A. Saeed, dan M. Ajaib, "A review on the phytochemistry and pharmacology of genus Tephrosia", Phytopharmacology, vol. 4, no. 3, pp. 598637., 2013.

[10] V. Razafintsalama, S. Sarter, L. Mambu, R. Randrianarivo, Th. Petit, J. F. Rajaonarison, Chr. Mertz, D. Rakoto, dan V. Jeannoda., "Antimicrobial activities of dilobeia thouarsii Roemer and schulte, a traditional medicinal plant from Madagascar," South African Journal of Botany, vol. 87, pp. 1-3., 2013.

[11] Y. J. Kang, Y. L. Yi, Ch. Zhang, Sh. Q. Wu, C. B. Shi, dan G. X. Wang, "Bioassay-guide isolation and identification of active compounds from Macleaya microcarpa (Maxim) Fedde against fish pathogenics bacteria.", Aquaculture Research, vol. 44, no. 8, pp. 1221-1228., 2013.

[12] J.B. Patel, et al "Performance Standards for Antimicrobial Disk Susceptibility Tests; Approved Standard-Twelfth Edition," USA: CLSI, 2015.

[13] J.N. Vasconcelos, G.M.P. Santiago, J.Q. Lima, J. Mafezoli, T.L.G. de Lemos, F.R.L. da Silva, M.A.S. Lima, A.T.A. Pimenta, R. Braz-Filho, A.M.C. Arriaga, dan D. CesarinSobrinho, "Rotenoids from Tephrosia Toxicaria with Larvacidal Activity Against Aedes aegypti, The Main Vector of Dengue Fever', Quim Nova, vol. 35, no. 6, pp. 10971100.

[14] Greenwood, Antibiotic Susceptibility (sensitivity) test, antimicrobial and Chemotherapy. USA: Mc Graw Hill Company, 1995. 